\title{
2. The maturing of a profession
}

\author{
John Ridge AM \\ Australian Computer Society (ACS) Foundation
}

There is a significant difference between a person being considered to be 'professional' in their approach to conducting business, whatever that business may be, and a person being part of a profession and therefore considered to be a professional. This difference has created enormous misunderstanding and confusion within the information and communications technology (ICT) sector, and hampered its progress towards being recognised as a profession. Being part of a profession is a vocation requiring knowledge of some department of learning or science, for example, medicine, law, engineering, architecture, accountancy and, more recently, ICT.

Technology, and particularly ICT, more than anything else in recent times, has forever changed our lives and will continue to do so at an ever-increasing rate. Today, anyone with an Internet connection can access overwhelming amounts of information and enjoy instant, global communications. Technology is also the primary enabler and driver of growth in just about every other industry. Without a vibrant, dynamic and innovative ICT sector, Australia will be unable to achieve world-leading innovation in these other industries. ICT is driving the significant innovation and advances in medicine, science and mining, amongst other fields. Without ICT the mapping of the human genome would not have been possible. ICT has an important and positive influence on the economy and on productivity, where it is responsible for around 17 per cent of productivity gains. Growth in ICT has an economic multiplier factor of between five and 10 times in other associated areas. This means that in terms of both dollars invested and employment in ICT, there is a factor of five to 10 times the benefit flowing into other parts of the economy.

Yet, despite the fundamental importance of ICT to so many other industries and to the economy, very few know or recognise that ICT has the status of a profession and that ICT professionals belong to one of the learned or skilled professions. In January 2000, the Australian Computer Society (ACS) was admitted to the Australian Council of Professions - since renamed Professions Australia - as the membership body formally representing the ICT profession. Professions Australia is the peak body for all professions in Australia and includes representatives of medicine, law, accounting, engineering and architecture, amongst other professions. The ACS's membership was the culmination of more than five years work by a committed team, and it meant that ICT had finally 
come of age! The final decision was made by the 30 or so other professional associations represented by Professions Australia. This recognised ICT as a profession, making the ACS the first computer society in the world to achieve this status in its own right. As president of the ACS at that time, I was privileged to share the excitement at this achievement.

The ACS is one of a number of professional bodies for ICT that offers membership to ICT practitioners. Obtaining the status of a profession requires professional bodies to set suitable standards of knowledge and codes of conduct. Professionalism is absolutely fundamental to the effective practice of ICT.

The ACS is involved in the development and monitoring of educational programs and accredits ICT courses that meet the standard of the ACS Professional Standards Board (Core) Body of Knowledge (CBOK). It has set standards of knowledge and experience for professionals and has codes of ethics, conduct and professional practice.

Any organisation would want its ICT staff to be professional in their practice, and to be recognised and accepted as being professionals. The benefits to organisations and society include practitioners having an adequate level of knowledge, providing a higher level of products and services, and abiding by professional standards and codes of ethics. It would be plausible to think that organisations, as a way of guaranteeing professionalism, would seek to employ ICT practitioners who are part of the profession and members of a professional body.

One problem is that membership of a professional body is not a prerequisite for ICT practitioners to practice, unlike other professions such as law or accounting. In most of these professions, membership of a professional body is inextricably linked to the ability to practice, either in reality or by common perception and, in some cases, the loss of that professional membership results in the loss of the right to practice. The absence of this professional obligation in ICT can result in practitioners employing haphazard levels of knowledge, with inadequate understanding of codes of ethics and professional practice.

To be clear, as with many other disciplines there is a 'full spectrum' of ICT practitioners, ranging from people who have relevant university degrees and a minimum level of experience, through TAFE and industry certifications, to those who have gained their skills from on-the-job training and experience. The role of the professional body is to establish the standard criteria to differentiate a practitioner from a professional.

The ACS currently has more than 22,000 members, which, on a per capita basis, places it amongst the top two or three computer societies in the world. Approximately 20 per cent of that number would be practitioners, and the 
remainder would be professionals. Depending on the data used to calculate the number of ICT professionals in Australia, however, that membership represents approximately 6.5 per cent of the total. So, it is reasonable to conclude that only a small proportion of ICT practitioners understand or recognise the value of belonging to a professional body. Compare this to other professions in which almost 100 per cent of practitioners belong to their appropriate professional body. Changing this attitude will require the combined approach and resources of the whole ICT industry - employers, practitioners, academics, government and industry associations.

Another problem, which may be due to the limited membership of the relevant professional body, is that ICT practitioners and society in general do not regard ICT as a profession. ICT's recognition as a profession in 2000 did not generate significant publicity and ICT's public profile remains slight.

The ICT industry needs to promote its status as a profession. It needs to promote the value of ICT and how technology has changed and will continue to change the practice of other industries. And it needs to promote professionalism in the ICT industry in general. Changing attitudes and public perception will have beneficial effects on enrolments of students in ICT and the quality of those students.

I was excited when the ACS was admitted to Professions Australia. It meant that ICT had come of age as a profession and was recognised as such. Parents who want a professional career for their children could now consider ICT as a legitimate choice. More importantly, ICT practitioners would be proud to be recognised as being part of a profession, joining their professional body, and adhering to a recognised code of conduct and ethics.

Jo Coldwell in 'Professional ethics and responsibilities' considers this issue in some depth. She concludes that ICT is, 'an immature profession which will develop into a fully recognised one as governments and employers recognise the benefits of a registration process that becomes an expected prerequisite to employment within the industry' (Coldwell, 2008). Using the example of an architect, Coldwell discusses three components that are required for a person to become registered, which include: demonstrated meeting of the academic requirements; completion of two years practical experience; and, completion of a professional practice component, which focuses on legal, contractual and business matters. She also talks about the eight characteristics of the infrastructure surrounding and supporting a profession such as architecture. Six of those eight components currently exist for ICT and are met by the ACS. The remaining two components pertain to licensing or registration. There are 
currently no requirements for ICT practitioners to be licensed or registered in Australia (or even to be members of a professional body) in order for them to practice.

The ICT profession or industry may not yet be ready to implement a licensing or registration process. It should start, however, with professional membership as a requirement to practice as a first step. As membership becomes more pervasive, widespread and accepted, registration may well be the next logical step.

Recent surveys show that a majority of ICT practitioners do not truly understand, recognise or value being a part of a profession or holding professional membership. This attitude stems from a lack of understanding of what being a part of a profession represents. Most practitioners would consider themselves as being professional and seek to act professionally in their day-to-day activities, but they may not necessarily consider themselves as being a part of a profession, or recognise ICT as a profession.

Organisations, like the ACS, need to do more to make the public, current ICT practitioners and students aware that ICT is a recognised profession. This can be achieved through extensive media coverage. As practitioners and professionals, we need to promote the view that ICT is a profession and, as such, it requires members of the profession to belong to a professional body.

The standard for the Core Body of Knowledge, which underpins professional accreditation, must be driven by our industry in collaboration with academia. We need to speak with a single voice and be championed by our ICT executives who are able to bring local and global perspectives to bear on the issue. Imagine how much more effective this would be than the current system, where there are separate advisory groups (advising, for example, on issues related to curricula and skills relevant to industry) at each of the 38 universities performing a similar function independently. Consider if we all worked together as one how efficiently we could effect change and improve productivity. Course curricula must be meaningful to business and industry requirements, and training and professional development needs to be nationally consistent.

The longer the industry takes to implement a campaign to make people aware that ICT is a recognised profession, the longer it will take to attract high-calibre students to the industry - an industry on which all other industries rely. The maturing of the ICT profession now needs to be widely communicated.

\section{Reference}

Coldwell, J, 2008, 'Professional ethics and responsibilities', in D McDermid (ed), Ethics in ICT: an Australian perspective, Pearson Education Australia, Frenchs 